\title{
Synergistic effect of benzylaminopurine and meta-Topolin combination for micropropagation of gerbera 'Pink Melody'
}

\section{Efeito sinérgico da combinação de benzilaminopurina e meta-Topolina para micropropagação de gerbera 'Pink Melody'}

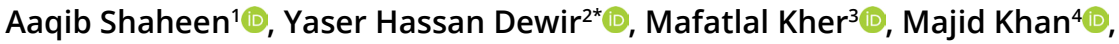 \\ Antar Nasr El-Banna ${ }^{5}$, Ahmed Alaizari2 ${ }^{(1)}$
}

${ }^{1}$ Henan University, College of Agriculture, School of Life Sciences, Kaifeng, Henan, China

${ }^{2}$ King Saud University, College of Food and Agriculture Sciences, Plant Production Department, Riyadh, Saudi Arabia

${ }^{3}$ GSFC University, School of Science, Vadodara, Gujarat, India

${ }^{4}$ Chinese Academy of Agricultural Sciences, Institute of Cotton Research, Anyang, Henan, China

5ulius Kühn-Institute/JKI, Federal Research Centre for Cultivated Plants, Institute for Epidemiology and Pathogen Diagnostics, Braunschweig, Germany

*Corresponding author: ydewir@ksu.edu.sa

Received in August 20, 2021 and approved in November 25, 2021

\begin{abstract}
Gerbera (Gerbera jamesonii Bolus ex Hook. F.; Asteraceae), is one of the most economically important ornamental plants due to its aesthetic value. In the present study, we established a micropropagation method for the large-scale production of quality planting material of gerbera 'Pink Melody'. Eighty-six percent of the capitulum explants produced adventitious shoots (15.44 \pm 0.34 shoots per capitulum) on Murashige and Skoogs (MS) medium containing $2 \mathrm{mg} \mathrm{L}^{-1} 6$-benzylaminopurine (BAP) after six weeks of incubation. The highest shoot multiplication rate (17 shoots per explant) was obtained on MS medium supplemented with BAP and meta-Topolin (each at 2 mg $\mathrm{L}^{-1}$ )

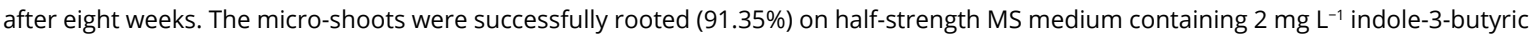
acid (IBA) within four weeks. The micropropagated plantlets were acclimatized with a $97.5 \%$ survival rate and produced flowers with no visible morphological aberrations.
\end{abstract}

Index terms: Acclimatization; Asteraceae; floriculture; tissue culture.

\begin{abstract}
RESUMO
A Gérbera (Gerbera jamesonii Bolus ex Hook. F.; Asteraceae) é uma das plantas ornamentais economicamente mais importantes devido ao seu valor estético. No presente estudo, estabelecemos um método de micropropagação para a produção em larga escala de material de plantio de qualidade de gérbera 'Pink Melody'. Oitenta e seis por cento dos explantes do capítulo produziram brotos adventícios (15,44 \pm 0,34 brotos por capítulo) em meio Murashige e Skoogs (MS) contendo $2 \mathrm{mg} \mathrm{L}^{-1}$ de 6-benzilaminopurina (BAP) após seis semanas de incubação. A maior taxa de multiplicação de brotos (17 brotos por explante) foi obtida em meio MS suplementado com BAP e metaTopolina (cada um a $2 \mathrm{mg} \mathrm{L}^{-1}$ ) após oito semanas. Os micro-brotações foram enraizados com sucesso (91,35\%) em meio MS de meia força contendo $2 \mathrm{mg} \mathrm{L}^{-1}$ de ácido indol-3-butírico (AIB) em quatro semanas. As plântulas micropropagadas foram aclimatadas com uma taxa de sobrevivência de $97,5 \%$ e produziram flores sem aberrações morfológicas visíveis.
\end{abstract}

Termos para indexação: Aclimatação; Asteraceae; floricultura; cultura de tecidos.

\section{INTRODUCTION}

Gerbera (Gerbera jamesonii Bolus ex Hook. $\mathrm{f}$; Asteraceae) is a popular ornamental plant in the floriculture industry, ranked among the ten most highly traded ornamental flowering plants in the world (Xia et al., 2006; Mosqueda Frómeta et al., 2017). The market value of gerbera is high in the UK, USA, Japan, and Germany, while the Netherlands, Indonesia, and Malaysia are the leading gerbera suppliers (Rashmi et al., 2018). Gerberas are ranked $5^{\text {th }}$ among cut flower sales in the Netherlands at 140 million euros and $4^{\text {th }}$ in terms of production with 1.07 billion units produced annually (Royal Flora of Holland, 2017). Considering the global demand, gerberas could provide a significant source of revenue generation from international markets. 
Gerbera can be grown from seed as well as propagated via vegetative methods. However, a limited number of plants can be obtained through vegetative propagation and the transmission of disease from stock plants is common (Kanwar; Kumar, 2008; Cardoso; Teixeira da Silva, 2013). Plants that are obtained via seed germination are not genetically uniform and are prone to seed-borne diseases. Alternatively, micropropagation techniques are extensively utilized for large-scale propagation of ornamental and horticulturally important plants, including gerbera (Cardoso; Teixeira da Silva, 2013). Additionally, genetic engineering can be applied to micropropagation methods to develop qualitative traits such as color variation, fragrance, shelf-life, shape, and resistance to biotic or abiotic stress (Kishi-Kaboshi et al., 2018; Pramanik et al., 2021).

Different explants have been utilized for micropropagation of gerbera, including shoot tips, leaves, flower buds, ovules, and capitulum (Cardoso; Teixeira da Silva, 2013). Shoot tip culture methods are preferred for micropropagation of gerbera, but a large number of shoot tips are required for commercial-scale production and the rate of contamination is high due to the presence of trichomes (Murashige et al., 1974; Rashmi et al., 2018). The main benefit of using capitulum over shoot tips is the minimal potential for contamination (Murashige et al., 1974; Cardoso; Teixeira da Silva, 2013). Moreover, the shoot regeneration potential of the capitulum is higher than that of leaf explants (Tyagi; Kothari, 2004).

The gerbera 'Pink Melody' is a high-yielding cultivar with pink semi-double flowers (Park et al., 2018). In the present study, we have used capitulum explants to develop a micropropagation protocol for this commercially important cultivar. Although, earlier attempts have been made for micropropagation of gerbera using capitulum (Pierik; Steegmans; Marelis, 1973; Pierik, 1975; Tyagi; Kothari, 2004; Ray; Saha; Roy, 2005; Mohammed; Özzambak, 2007; Chakrabarty; Datta, 2008; Askari Rabori; Fotouhi Ghazvini, 2009; Bhatia et al., 2009, 2011, 2012; Fakhrfeshani et al., 2012; Shylaja et al., 2014; Gautam et al., 2017; Rashmi et al., 2018; Talla et al., 2019; Winarto; Yuniarto; Soehendi, 2020). It is also essential to optimize the conditions for acclimatization and flowering potential of micropropagated plants in the field condition (Cardoso et al., 2013). To best of our knowledge, this is the first report on micropropagation and subsequent acclimatization of gerbera 'Pink Melody' from capitulum explant using combination of 6-benzylaminopurine and meta-Topolin. The aim of the present research was to develop an efficient micropropagation protocol of G. jamesonii 'Pink Melody' and acclimatization of micropropagated plants.

\section{MATERIAL AND METHODS}

\section{Explant surface disinfection}

This research was carried out in the tissue culture laboratory of Qarshi Research International (Research Division), Qarshi Industries (Pvt) Ltd., Pakistan. Capitulum explants (size: $\sim 1.5 \mathrm{~cm}$ ) were collected during early morning before sunrise during winter season from mature Gerbera jamesonii Bolus ex Hook. f 'Pink Melody' plants grown at the Qarshi Herbal Research Centre gardens. The explants were washed under running tap water for $30 \mathrm{~min}$, then submerged in $1 \%$ fungicide solution (FungiGone ${ }^{\mathrm{TM}}$ Dublin, USA) for $5 \mathrm{~min}$. Next, the explants were rinsed for $20 \mathrm{~min}$ in a $10 \%$ solution of $2.5 \%$ sodium hypochlorite (SigmaAldrich, Merck KGaA, Darmstadt, Germany) with 1-2 drops of Tween 20 , followed by $10 \mathrm{~min}$ in $0.1 \%$ mercuric chloride. Finally, the explants were rinsed $4-5$ times with sterile distilled water to remove the disinfectants.

\section{Culture initiation}

The capitulum was prepared by removing the both disc flowers and ligulate ray flowers, excluding the receptacle and peduncle (Pierik; Steegmans; Marelis, 1973; Pierik, 1975). Then explants were cultured on glass jars (capacity: $250 \mathrm{~mL}$ ) containing $50 \mathrm{~mL}$ of MS Murashige-Skoog (MS) medium (Murashige; Skoog, 1962) supplemented with $2 \mathrm{mg} \mathrm{L}^{-1}$ 6-benzylaminopurine (BAP), 2\% (w/v) sucrose, and $0.8 \%(\mathrm{w} / \mathrm{v})$ agar-agar. The $\mathrm{pH}$ of the medium was adjusted to 5.8 prior to autoclaving at $121^{\circ} \mathrm{C}$ and $1.2 \mathrm{~kg} \mathrm{~cm}^{-2}$ for $20 \mathrm{~min}$. All cultures were incubated at $25{ }^{\circ} \mathrm{C} \pm 2{ }^{\circ} \mathrm{C}$ under cool-white fluorescent lights that provided a $16: 8 \mathrm{~h}$ photoperiod of $35 \mu \mathrm{mol}$ $\mathrm{m}^{-2} \mathrm{~s}^{-1}$ photosynthetic photon flux density (PPFD). The percentages of survival, number of explants forming adventitious shoots, and number of adventitious shoots per explant were recorded after six weeks in culture. Capitulum-derived shoots were sub-cultured on the initiation medium, followed by three subcultures on MS without plant growth regulators (PGRs) to obtain sufficient materials for the shoot multiplication experiments.

\section{Shoot multiplication}

Shoots $(\sim 1 \mathrm{~cm}$ in length) raised in vitro were inoculated into $250 \mathrm{~mL}$ glass jars containing $50 \mathrm{~mL}$ MS medium with combination of $2 \mathrm{mg} \mathrm{L}^{-1}$ meta-Topolin (mT) with 1.0 to $6 \mathrm{mg} \mathrm{L}^{-1}$ 6-benzylaminopurine (BAP) and combinations of $2 \mathrm{mg} \mathrm{L}^{-1} \mathrm{BAP}$ with $2 \mathrm{mg} \mathrm{L}^{-1}$ 2,4-dichlorophenoxyacetic acid (2,4-D) and thidiazuron (TDZ) and 1-3 $\mathrm{mg} \mathrm{L}^{-1}$ gibberillic acid $\left(\mathrm{GA}_{3}\right)$. Each 
treatment consisted of five jars and each jar contained three shoots. The medium was gelled using $0.8 \%(\mathrm{w} / \mathrm{v})$ agaragar, and the $\mathrm{pH}$ was adjusted to 5.8 before autoclaving at $121{ }^{\circ} \mathrm{C}$ and $1.2 \mathrm{~kg} \mathrm{~cm}^{-2}$ for $20 \mathrm{~min}$. All cultures were incubated at $25{ }^{\circ} \mathrm{C} \pm 2{ }^{\circ} \mathrm{C}$ under cool-white fluorescent lights that provided a $16: 8 \mathrm{~h}$ photoperiod of $35 \mu \mathrm{mol} \mathrm{m}{ }^{-2}$ $\mathrm{s}^{-1}$ PPFD. After eight weeks, the number of shoots per explant and the length of the main shoots were recorded.

\section{In vitro rooting}

Proliferated axillary shoots $(\sim 3 \mathrm{~cm}$ in length) with two expanded leaves were cultured on full or half strength MS without PGRs, or half-strength MS supplemented with indole-3-acetic acid (IAA) or indole-3-butyric acid (IBA) at the concentration of 1,2 , and $3 \mathrm{mg} \mathrm{L}^{-1}$. Each treatment consisted of five replicate jars, each with three shoots. After four weeks in culture, the percentage of rooting, number of roots per explant, length of the main root, and number of leaves were recorded.

\section{Acclimatization}

The adhered agar was removed from the rooted plant using clean water. The plantlets were transferred in plastic trays ( 48 wells, $1.5 \times 2.25 \mathrm{~cm}$ ) containing peat moss covered with a transparent polyethylene plastic cover for acclimatization. The plantlets were kept in a growth room at $25^{\circ} \mathrm{C} \pm 2{ }^{\circ} \mathrm{C}$ under a $16: 8 \mathrm{~h}$ light/dark photoperiod for three weeks before they were transferred to the greenhouse. The acclimatized plants were transferred to small poly-plastic bags (20 length $\times 15 \mathrm{~cm}$ diameter) containing different combinations (equal volume) of potting mixtures of soil, sand, silt, coco coir, peat moss, and compost (mixed with manure). The plantlets were regularly irrigated using a nutrient solution that contained half-strength MS basal salts. Each treatment had three replicates and each replicate contained nine pots. After 15 weeks, growth parameters (percent survival, days to first flowering, number of flowers per plant, flower diameter, and peduncle length) were measured and recorded.

\section{Experimental design and statistical analysis}

The experiment was conducted in a completely randomized design. For all in vitro culture experiments, there were five replicates in each treatment and each replicate was represented by a culture vessel (Magenta GA-7) containing three explants rendering a group of 15 explants per treatment. The quantitative data were presented as mean \pm standard error (SE) of three repeated experiments. All data were analyzed quantitatively by analysis of variance using STATISTIX 8.1 software,
(Statistix, Analytical Software, Statistix; Tallahassee, FL, USA). Tukey's multiple range test was used to determine significant differences between means at $P \leq 0.05$.

\section{RESULTS AND DISCUSSION}

\section{Culture initiation}

Micropropagation of various gerbera cultivars using different types of explants, including capitulum, has been reviewed (Kanwar; Kumar, 2008; Cardoso; Teixeira da Silva, 2013). The type and concentration of plant growth regulators (PGRs) required for in vitro morphogenesis is dependent on the type of explant, genotype or species (Meyer; Van Staden, 1988; Nhut et al., 2007), and media composition (Bhatia; Singh; Singh, 2012; Niedz et al., 2014). Thus, cultivar-specific optimized protocols are required for the commercialscale cultivation of gerbera.

For commercial level micropropagation, 6-benzylaminopurine (BAP) is used due to its cost and it is also autoclaved. Among the capitulum explants, $86.42 \%$ showed shoot regeneration on culture initiation medium [MS $+2 \mathrm{mg} \mathrm{L}^{-1} \mathrm{BAP}$, with an average of $15.44 \pm 0.34$ shoots per capitulum after six weeks (Table 1; Figure 1AB). A previous study on Gerbera aurantiaca reported that only one out of twenty capitulum showed shoot regeneration on MS containing $5 \mu \mathrm{M}\left(\sim 1.1 \mathrm{mg} \mathrm{L}^{-1}\right)$ BAP (Meyer; Van Staden, 1988). A combination of $7 \mathrm{mg} \mathrm{L}^{-1}$ BAP and 0.1 $\mathrm{mg} \mathrm{L}^{-1}$ indole 3 acetic acid (IAA) produced $\sim 4.6$ shoots/ capitulum in unknown cultivar (Ray; Saha; Roy, 2005). On modified MS medium (MS major salts and iron $1 / 2$ strength along with MS vitamins and Heller's medium excluding $\mathrm{FeCl}_{3}$ supplemented with $2 \mathrm{mg} \mathrm{L}^{-1} \mathrm{BAP}$ and 0.5 $\mathrm{mg} \mathrm{L}^{-1}$ indole 3 acetic acid (IAA) produced $\sim 4.5$ shoot per explant in $72.7 \%$ cultures (Mandal; Datta, 2002). While, 4 shoots/capitulum was obtained on MS medium with $4 \mathrm{mg}$ $\mathrm{L}^{-1}$ Kinetin with $0.05 \mathrm{mg} \mathrm{L}^{-1}$ IAA (Tyagi; Kothari, 2004). In another study, $\sim 5.6$ shoots/capitulm in G. jamesonii $c v$. Jaimy and $\sim 4.6$ shoots in G. jamesonii $c v$. Mammut obtained from MS medium supplemented with $0.5 \mathrm{mg}$ $\mathrm{L}^{-1}$ and $0.1 \mathrm{mg} \mathrm{L}^{-1}$ thidaizuron (TDZ) respectively. Askari Rabori and Fotouhi Ghazvini (2009) reported only 5.6 shoots/capitulm in G. jamesonii cv. 'Jaimy' and $\sim 4.6$ shoots in G. jamesonii cv. 'Mammut' obtained from MS medium supplemented with $0.5 \mathrm{mg} \mathrm{L}^{-1}$ and $0.1 \mathrm{mg} \mathrm{L}^{-1}$ thidaizuron (TDZ) respectively. Bhatia, Singh and Singh (2012) and Talla et al. (2019) reported $\sim 16$ shoots per capitulum explant of gerbera 'Cabana' (MS+ $5 \mathrm{mg} \mathrm{L}^{-1} \mathrm{BAP}+0.2 \mathrm{mg} \mathrm{L}^{-1}$ IAA) and 'Terra Regina' (MS+ $4 \mathrm{mg} \mathrm{L}^{-1} \mathrm{BAP}+0.2 \mathrm{mg} \mathrm{L}^{-1}$ 
$\alpha$-naphthalene acetic acid). Mosqueda Frómeta et al. (2017) used modified MS medium with half the level of nitrate along with $800 \mathrm{mg} \mathrm{L}^{-1}$ calcium nitrate, $1.0 \mathrm{mg} \mathrm{L}^{-1} \mathrm{BAP}, 0.5$ $\mathrm{mg} \mathrm{L^{-1 }}$ NAA for shoot multiplication from a shoots with at least one leaf blade in a temporary immersion bioreactor system, which produce 9 shoots/explant. Therefore, each cultivar requires specific concentrations and combinations of PGRs for optimum shoot regeneration.

\section{Shoot multiplication}

For the optimization of shoot multiplication protocol, in vitro raised shoots from capitulum $(\sim 1 \mathrm{~cm}$ shoot length) were subcultured on the MS medium supplemented on various PGRs (Table 2). Shoots were unable to multiply on the plant growth regulator (PGR) free medium. While, a significant increase in shoot multiplication rate has been observed on MS medium containing PGRs (Table 2).
On MS medium supplemented with a combination of $1 \mathrm{mg} \mathrm{L}^{-1}$ BAP with $2 \mathrm{mg} \mathrm{L}^{-1}$ meta-Topolin (mT) produced $10 \pm 0.17$ with $2.10 \pm 0.14 \mathrm{~cm}$ shoot length. Highest shoot multiplication $17 \pm 0.45$ shoots with shoot length of $4.38 \pm 0.09 \mathrm{~cm}$ was obtained on MS medium supplemented with $2 \mathrm{mg} \mathrm{L}^{-1}$ BAP and $\mathrm{mT}$ (Table 2; Figure $1 \mathrm{C}$ ). Interestingly, shoot multiplication rate has been decreased in cultures having MS medium with 3-6 $\mathrm{mg} \mathrm{L}^{-1}$ of BA with $2 \mathrm{mg} \mathrm{L}^{-1} \mathrm{mT}$ (Table 2). A synergistic effects of combination of two cytokinin on the shoot multiplication of various plants has been reported for e.g. BAP with Kn in Bambusa glaucescens (Shirin; Rana, 2007) and $\mathrm{mT}$ with $\mathrm{Kn}$ in Maytenus emarginata (Shekhawat et al., 2020). In contrast, sometime combination of two cytokinin (Kn with BA) may produce negative impact on shoot multiplication as in case of Scoparia dulcis (Premkumar et al., 2011).

Table 1: Percentages shoot regeneration and number of shoots of Gerbera jamesonii 'Pink Melody' on MS medium with $2 \mathrm{mg} \mathrm{L}^{-1} 6$-benzylaminopurine after 6 weeks in culture.

\begin{tabular}{cccc}
\hline Explant type & Survival (\%) & Explants forming adventitious shoots (\%) & Adventitious shoot (number/explant) \\
\hline Capitulum & $65 \pm 3.90$ & $86.42 \pm 3.60$ & $15.44 \pm 0.34$ \\
\hline
\end{tabular}

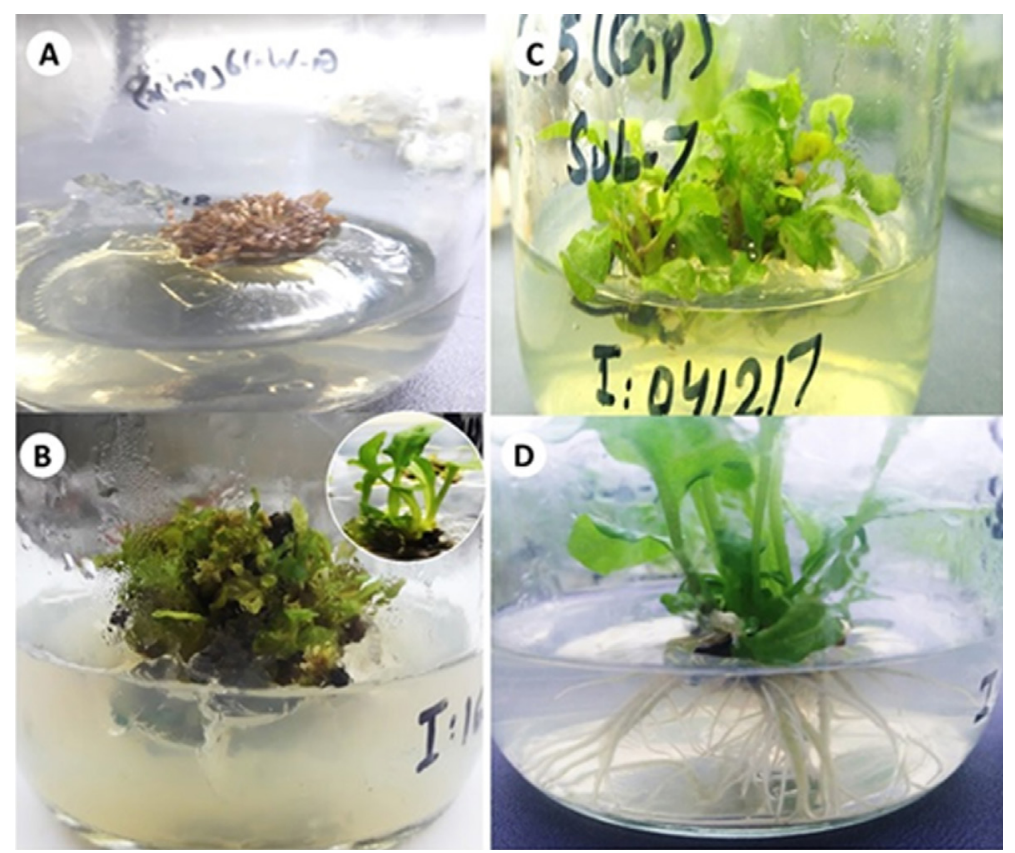

Figure 1: Micropropagation of Gerbera jamesonii 'Pink Melody.' A) Capitulum explant cultured on MurashigeSkoog (1962) medium (MS) with $2 \mathrm{mg} \mathrm{L}^{-1}$ 6-benzylaminopurine (BAP). B) Adventitious shoot regeneration and shoot development (inset) on the same initiation medium. C) Axillary shoot multiplication on MS supplemented with $2 \mathrm{mg} \mathrm{L}^{-1}$ BAP and $2 \mathrm{mg} \mathrm{L}^{-1}$ meta-Topolin after eight weeks, and D) In vitro rooting on half-strength MS medium with $2 \mathrm{mg} \mathrm{L}^{-1}$ indole-3-butyric acid after four weeks. 
Table 2: Effect of different combinations of plant growth regulators on the in vitro shoot multiplication of Gerbera jamesonii 'Pink Melody' after an 8-week subculture period (every four week). The medium without cytokinin was served as the control.

\begin{tabular}{|c|c|c|}
\hline Growth regulators & Shoot number/explant & Length of the main shoot $(\mathrm{cm})$ \\
\hline Control & $1.0 \pm 0.00 \mathrm{~g}^{2}$ & $1.55 \pm 0.59 f^{z}$ \\
\hline $1 \mathrm{mg} \mathrm{L}^{-1} \mathrm{BAP}+2 \mathrm{mg} \mathrm{L}^{-1}$ meta-Topolin & $10 \pm 0.17 b$ & $2.10 \pm 0.14$ ef \\
\hline $2 \mathrm{mg} \mathrm{L}^{-1} \mathrm{BAP}+2 \mathrm{mg} \mathrm{L}^{-1}$ meta-Topolin & $17 \pm 0.45 a$ & $4.38 \pm 0.09 a$ \\
\hline $3 \mathrm{mg} \mathrm{L}^{-1} \mathrm{BAP}+2 \mathrm{mg} \mathrm{L}^{-1}$ meta-Topolin & $11 \pm 0.33 b$ & $2.26 \pm 0.10$ de \\
\hline $4 \mathrm{mg} \mathrm{L}^{-1} \mathrm{BAP}+2 \mathrm{mg} \mathrm{L}^{-1}$ meta-Topolin & $9 \pm 0.24 c$ & $2.84 \pm 0.12 \mathrm{bcd}$ \\
\hline $5 \mathrm{mg} \mathrm{L}^{-1} \mathrm{BAP}+2 \mathrm{mg} \mathrm{L}^{-1}$ meta-Topolin & $8 \pm 0.33 c$ & $3.39 \pm 0.23 b$ \\
\hline $6 \mathrm{mg} \mathrm{L}^{-1} \mathrm{BAP}+2 \mathrm{mg} \mathrm{L}^{-1}$ meta-Topolin & $7 \pm 0.24 d$ & $2.99 \pm 0.04 b c$ \\
\hline $2 \mathrm{mg} \mathrm{L}^{-1} \mathrm{BAP}+2 \mathrm{mg} \mathrm{L}^{-1} 2,4-\mathrm{D}$ & $7.4 \pm 0.24 \mathrm{~cd}$ & $2.75 \pm 0.11 \mathrm{~cd}$ \\
\hline $2 \mathrm{mg} \mathrm{L}^{-1} \mathrm{BAP}+2 \mathrm{mg} \mathrm{L}^{-1} \mathrm{TDZ}$ & $5.2 \pm 0.28 \mathrm{e}$ & $2.04 \pm 0.05$ ef \\
\hline $1 \mathrm{mg} \mathrm{L}^{-1} \mathrm{GA}_{3}$ & $5.1 \pm 0.20 \mathrm{e}$ & $2.83 \pm 0.07 \mathrm{bcd}$ \\
\hline $2 \mathrm{mg} \mathrm{L}^{-1} \mathrm{GA}_{3}$ & $5.3 \pm 0.29 \mathrm{e}$ & $4.29 \pm 0.18 \mathrm{a}$ \\
\hline $3 \mathrm{mg} \mathrm{L}^{-1} \mathrm{GA}_{3}$ & $4 \pm 0.17 f$ & $3.04 \pm 0.21 b c$ \\
\hline
\end{tabular}

${ }^{2}$ Values followed by the same letter in the same column are not significantly different at $P \leq 0.05$ level, according to Tukey's multiple range test. 2,4-D =2,4-dichlorophenoxyacetic acid, $B A P=6$-benzylaminopurine, $\mathrm{GA}_{3}=$ gibberillic acid, $T D Z=$ thidiazuron.

Meta-Topolin (mT) is an analogue of highly active cytokinin BAP. Efficacy of $\mathrm{mT}$ on in vitro shoot multiplication have been reported in number of plant species including Maytenus emarginata (Shekhawat et al., 2020), Pogostemon cablin (Lalthafamkimi et al., 2020), Allamanda cathartica (Khanam et al., 2020), Ribes grossularia (Kucharska et al., 2020) and Scaevola taccada (Shekhawat et al., 2021). Kamínek et al. (1987) studied the activities of mT and BAP on shoot bud regeneration in G. jamesonii $c v$ 'Helios' and 'Poinsettia' and found the $\mathrm{mT}$ to be more active. In contrast, Kasem (2018) reported that BAP was more efficient than $m T$ in shoot induction and multiplication of $G$. jamesonii Bolus $c v$. 'Winter Queen'. It indicates each genotype having specific response for in vitro morphogenesis (Winarto; Yuniarto; Soehendi, 2020). Moreover, it also shows a minor structural variation between $\mathrm{mT}$ and BAP could have a significant effect on in vitro regeneration potential of any explant (Bairu et al., 2007). To the best of our knowledge, this is the first report on the synergistic effect of combination of BAP and $\mathrm{mT}$ on shoot multiplication of gerbera. Several researchers have described the synergistic effect of two cytokinin (Dewir et al., 2020; Lavanya et al., 2016) or auxin and cytokinin (Khanam et al., 2020; Shekhawat et al., 2021) or combinations of two cytokinin with auxin (Shekhawat et al., 2020) is also reported. A combination of auxin with cytokinin have a positive impact on shoot multiplication in many plant species (Khanam et al., 2020; Shekhawat et al., 2021). However, in this study shoot multiplication rate is significantly lower as compare to BAP and $\mathrm{mT}$ (Table 2).

\section{Rooting and acclimatization}

The shoots cultured on medium without auxin showed poor rooting frequency about $16 \%$ and $~ 38 \%$ in full strength and half-strength MS, respectively. Reducing the salt concentration of MS is a routine practice for in vitro rooting of gerbera (Talla et al., 2019) because the nutrient requirement for root formation is much lower than that of shoot regeneration (Driver; Suttle, 1987). Enrichment of half-strength MS with either indole-3-acetic acid (IAA) or indole-3-butyric acid (IBA) had a substantial effect on in vitro rooting (Table 3; Figure 1D). The highest rooting frequency (91\%) and the root number (11 roots/explant) was observed in the presence of $2 \mathrm{mg} \mathrm{L}^{-1}$ IBA (Table 3). IBA is the most frequently used auxin for in vitro or ex vitro rooting (Kanwar; Kumar, 2008; Cardoso; Teixeira da Silva, 2013). However, IAA and NAA has also been used to stimulate in vitro rooting of some gerbera cultivars. For e.g. $90 \%$ root regeneration has been reported in 'Terra Regina' on $1 / 2$ MS medium with $1 \mathrm{mg}$ $\mathrm{L}^{-1} \mathrm{IAA}$ (Talla et al., 2019); similarly, $92.6 \%$ root regeneration in 'SciellaIt' has been obtained on $1 / 2$ MS with $1.5 \mathrm{mg} \mathrm{L}^{-1} \mathrm{IAA}$ (Gantait; Sinniah, 2014). About 2.1 roots per shoot with 2.52 $\mathrm{cm}$ length of roots have been obtained on MS medium with $0.5 \mathrm{mg} \mathrm{L}^{-1} \mathrm{NAA}$ with $1.5 \mathrm{~g} \mathrm{~L}^{-1}$ activated charcoal in Black Jack (Winarto; Yufdy, 2017). In Cabana cultivar, 100\% root 
regeneration was observed on $1 / 2 \mathrm{MS}$ medium supplemented with $1 \mathrm{mg} \mathrm{L}^{-1} \mathrm{NAA}$ (Bhatia; Singh; Singh, 2012).

The final success of any micropropagation technique is determined based on the survival of plantlets ex vitro (Figure 2 A-E). The highest survival rate $(97.5 \%)$ was observed in plantlets grown on an equal mixture of peat moss and soil; moreover, these plants showed early flowering at 66 days, with an average of 4 flowers per plant and peduncle lengths of $56 \mathrm{~cm}$ (Table 4). Nutrient availability is the main determining factor for the suitability of plant-growing substrates (Caballero et al., 2007). Our results demonstrate that the largest flower diameter (5.3 $\mathrm{cm})$ was obtained in peat moss, while the smallest flower diameter $(2.84 \mathrm{~cm})$ with obtained in garden soil (Table 4). Ahmad et al. (2012) highlighted similar findings, in which growing substrates influenced flower stalk length, diameter, and flower quality of G. jamesonii 'Hybrid Mix'. In the present study, all in vitro raised plantlets were without any morphological variation (vegetative as well as flowering) or pathological symptoms (Figure $2 \mathrm{C}, \mathrm{D}$ and $\mathrm{E}$ ).

Table 3: Effect of indole-3-acetic acid (IAA) and indole-3-butyric acid (IBA) concentrations and salt strength of Murashige and Skoog's (MS) medium on in vitro rooting of Gerbera jamesonii 'Pink Melody' after a 4-weeks.

\begin{tabular}{|c|c|c|c|c|c|}
\hline Auxins (mg L-1) & & Rooting (\%) & $\begin{array}{c}\text { Roots } \\
\text { (no./per plantlet) }\end{array}$ & $\begin{array}{l}\text { Length of the } \\
\text { main root }(\mathrm{cm})\end{array}$ & $\begin{array}{c}\text { Leaves } \\
\text { (no./plantlet) }\end{array}$ \\
\hline MS without auxins & & $16.05 \pm 3.27 \mathrm{e}^{z}$ & $2.34 \pm 0.17 \mathrm{f}^{2}$ & $2.44 \pm 0.15 \mathrm{~cd}^{z}$ & $3 \pm 0.26 \mathrm{de}^{z}$ \\
\hline $1 / 2$ MS without auxins & & $38.14 \pm 1.85 \mathrm{~d}$ & $2.66 \pm 0.17 f$ & $3.26 \pm 0.20 b c$ & $4 \pm 0.22 \mathrm{~cd}$ \\
\hline $1 / 2 \mathrm{MS}+\mathrm{IAA}$ & 1 & $50.61 \pm 1.95 \mathrm{c}$ & $6.44 \pm 0.18 \mathrm{~d}$ & $2.97 \pm 0.25 c$ & $3 \pm 0.26 \mathrm{e}$ \\
\hline 2 & & $56.79 \pm 2.23 \mathrm{c}$ & $9.66 \pm 0.17 b$ & $4.07 \pm 0.14 b$ & $6 \pm 0.20 \mathrm{~b}$ \\
\hline 3 & & $46.91 \pm 1.63 \mathrm{c}$ & $6.22 \pm 0.22 \mathrm{~d}$ & $3.17 \pm 0.35 b c$ & $4 \pm 0.18 c$ \\
\hline $1 / 2 \mathrm{MS}+\mathrm{IBA}$ & 1 & $53.08 \pm 3.60 c$ & $4.88 \pm 0.31 \mathrm{e}$ & $2.47 \pm 0.21 \mathrm{~cd}$ & $5 \pm 0.17 b$ \\
\hline 2 & & $91.35 \pm 2.47 \mathrm{a}$ & $11.4 \pm 0.24 \mathrm{a}$ & $5.63 \pm 0.18 a$ & $8 \pm 0.11 a$ \\
\hline 3 & & $80.85 \pm 2.62 \mathrm{~b}$ & $7.88 \pm 0.35 \mathrm{c}$ & $2.01 \pm 0.15 \mathrm{~d}$ & $3 \pm 0.18 \mathrm{de}$ \\
\hline
\end{tabular}

zValues followed by the same letter in the same column are not significantly different at $\mathrm{P} \leq 0.05$ level, according to Tukey's multiple range test.

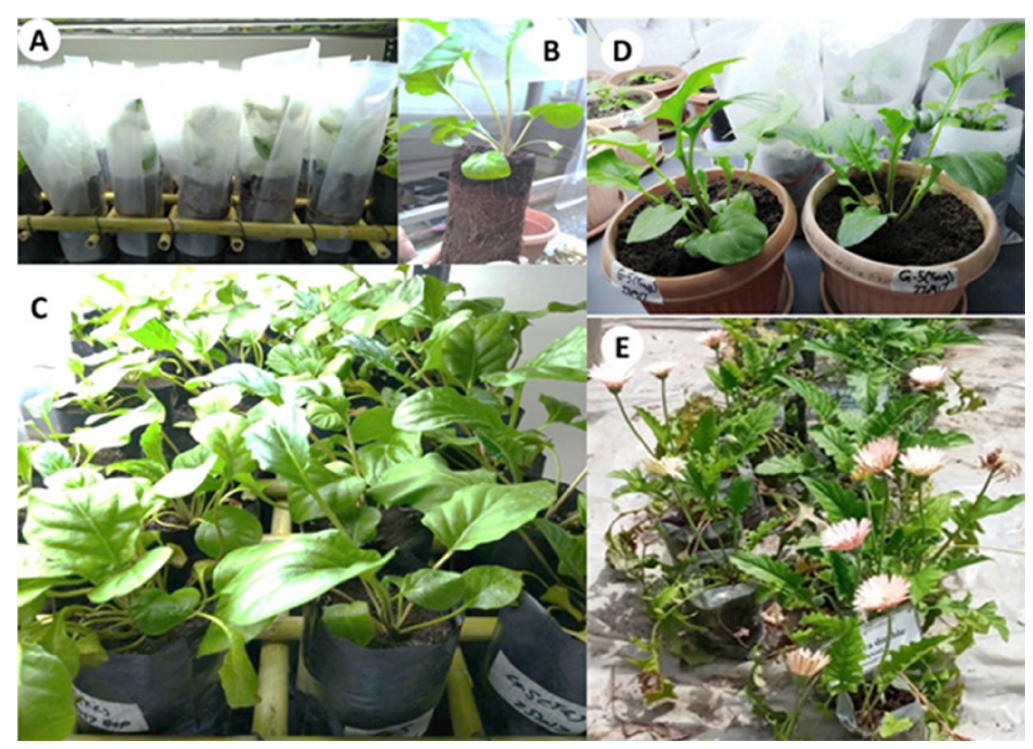

Figure 2: Acclimatization and growth of Gerbera jamesonii 'Pink Melody' A) Acclimatization in the growth chamber for three weeks, B) Plantlet with well-developed root system after three weeks in the growth chamber, C and D) Further growth of micropropagated plantlets after five and eight weeks in the greenhouse, respectively, and E) Flowering plant grown in peatmoss and soil $(1: 1, v / v)$ after 15 weeks in the greenhouse. 
Table 4: Effect of different growing media on acclimatization and flowering of Gerbera jamesonii 'Pink Melody' plantlets after 15 weeks in greenhouse.

\begin{tabular}{|c|c|c|c|c|c|}
\hline $\begin{array}{l}\text { Potting mixture } \\
\text { (by equal volume) }\end{array}$ & $\begin{array}{l}\text { Survival } \\
\text { (\%) }\end{array}$ & $\begin{array}{l}\text { Days to flower } \\
\text { emergence }\end{array}$ & $\begin{array}{l}\text { Flowers } \\
\text { (no./plant) }\end{array}$ & $\begin{array}{c}\text { Flower } \\
\text { diameter }(\mathrm{cm})\end{array}$ & $\begin{array}{l}\text { Peduncle } \\
\text { length }(\mathrm{cm})\end{array}$ \\
\hline Soil & $46.9 \pm 1.63 \mathrm{ef}^{2}$ & $74.667 \pm 0.75 \mathrm{cde}^{z}$ & $2 \pm 0.39 \mathrm{bcd}^{2}$ & $2.84 \pm 0.16 \mathrm{e}^{2}$ & $42.0 \pm 1.19 \mathrm{de}^{z}$ \\
\hline Soil + silt & $56.8 \pm 2.90 \mathrm{cde}$ & $76.667 \pm 0.29 \mathrm{abc}$ & $3 \pm 0.15 a b$ & $3.9 \pm 0.20 \mathrm{~cd}$ & $38.4 \pm 0.44 \mathrm{f}$ \\
\hline Soil + sand & $59.3 \pm 1.85 \mathrm{bcd}$ & $75.9 \pm 0.54 \mathrm{bcd}$ & $2 \pm 0.18 \mathrm{bcd}$ & $3.4 \pm 0.18 \mathrm{de}$ & $43.1 \pm 0.39 \mathrm{~d}$ \\
\hline Silt + sand & $50.6 \pm 2.69$ def & $76.8 \pm 0.43 \mathrm{abc}$ & $2 \pm 0.26 \mathrm{bcd}$ & $4.3 \pm 0.08 \mathrm{bc}$ & $39.0 \pm 0.47 f$ \\
\hline Soil + silt + sand & $61.7 \pm 1.95 \mathrm{bcd}$ & $77.9 \pm 0.45 a b$ & $1 \pm 0.18 d$ & $4.4 \pm 0.09 \mathrm{bc}$ & $42.0 \pm 0.33$ de \\
\hline Soil + sand + silt + coco coir & $69.1 \pm 2.47 b$ & $76.4 \pm 0.34 b c$ & $3 \pm 0.29 a b c$ & $4.6 \pm 0.07 \mathrm{abc}$ & $46.7 \pm 0.41 \mathrm{~b}$ \\
\hline $\begin{array}{c}\text { Soil + silt + sand + Manure } \\
\text { compost }\end{array}$ & $62.9 \pm 1.85 b c$ & $78.0 \pm 0.60 \mathrm{ab}$ & $2 \pm 0.36 \mathrm{bcd}$ & $3.9 \pm 0.23 \mathrm{~cd}$ & $40.4 \pm 0.50$ ef \\
\hline $\begin{array}{l}\text { Soil }+ \text { silt }+ \text { sand }+ \text { coco coir }+ \\
\text { manure compost }\end{array}$ & $56.7 \pm 2.23$ cde & $79.1 \pm 0.73$ a & $2 \pm 0.24 \mathrm{bcd}$ & $4.2 \pm 0.18 \mathrm{bcd}$ & $45.9 \pm 0.26 \mathrm{bc}$ \\
\hline Peat moss & $96.2 \pm 1.85 \mathrm{a}$ & $68.0 \pm 0.63 f$ & $4 \pm 0.32 \mathrm{a}$ & $5.3 \pm 0.12 \mathrm{a}$ & $55.2 \pm 0.43 a$ \\
\hline Peat moss + soil & $97.5 \pm 1.63 \mathrm{a}$ & $66.0 \pm 0.26 \mathrm{f}$ & $4 \pm 0.35 a$ & $4.9 \pm 0.26 \mathrm{ab}$ & $56.2 \pm 0.57 a$ \\
\hline Peat moss + soil + silt + sand & $53.0 \pm 3.09$ cde & $73.4 \pm 0.67$ de & $2 \pm 0.26 \mathrm{bcd}$ & $4.0 \pm 0.13 \mathrm{~cd}$ & $43.9 \pm 0.48 \mathrm{~cd}$ \\
\hline $\begin{array}{l}\text { Peat moss }+ \text { silt }+ \text { sand }+ \\
\text { manure compost }\end{array}$ & $40.7 \pm 2.62 f$ & $72.6 \pm 0.24 \mathrm{e}$ & $2 \pm 0.17 d$ & $3.9 \pm 0.21 \mathrm{~cd}$ & $42.8 \pm 0.52 \mathrm{de}$ \\
\hline $\begin{array}{l}\text { Peat moss }+ \text { soil }+ \text { silt }+ \text { sand }+ \\
\text { coco coir }+ \text { manure compost }\end{array}$ & $55.5 \pm 3.21 \mathrm{cde}$ & $79.1 \pm 0.48 a$ & $2 \pm 0.28 \mathrm{~cd}$ & $3.4 \pm 0.10 \mathrm{de}$ & $44.0 \pm 0.33 \mathrm{~cd}$ \\
\hline
\end{tabular}

2Values followed by the same letter in the same column are not significantly different at $\mathrm{P} \leq 0.05$ level, according to Tukey's range test.

\section{CONCLUSIONS}

An efficient method for the micropropagation of gerbera 'Pink Melody' has been established. This could enable large-scale propagation of this ornamental variety to meet its demand in floriculture industry. It is observed that the choice of explants (capitulum) with the adequate plant growth regulator type along with its concentration and combination plays a crucial role during culture initiation, multiplication and rooting of various gerbera varieties.

\section{AUTHOR CONTRIBUTION}

Conceptual Idea: Shaheen, A.; Methodology design: Shaheen, A.; Dewir, Y.H.; Kher, M.M.; Khan, M.; Data collection: Shaheen, A.; Khan, M.; Data analysis and interpretation: Shaheen, A.; Dewir, Y.H.; Kher, M.M.; Khan, M.; El-Banna, A.N.; Al-Aizari, A.A., and Writing and editing: Shaheen, A.; Dewir, Y.H.; Kher, M.M.; Khan, M.; El-Banna, A.N.; AlAizari, A.A.].

\section{ACKNOWLEDGEMENTS}

The authors acknowledge Researchers Supporting Project number (RSP-2021/375), King Saud University, Riyadh, Saudi Arabia.

\section{REFERENCES}

AHMAD, I. et al. Growth and flowering of gerbera as influenced by various horticultural substrates. Pakistan Journal of Botany, 44:291-299, 2012.

ASKARI RABORI, N.; FOTOUHI GHAZVINI, R. Shoot regeneration of Gerbera jamesonii cultivars from young capitulum. Acta Horticulture, 812:197-200, 2009.

BAIRU, M. W. et al. Optimizing the micropropagation protocol for the endangered Aloe polyphylla: Can meta-Topolin and its derivatives serve as replacement for benzyladenine and zeatin? Plant Cell, Tissue and Organ Culture, 90:15-23, 2007.

BHATIA, R. et al. Assessment of clonal fidelity of micropropagated gerbera plants by ISSR markers. Scientia Horticulturae, 119(2):208-211, 2009. 
BHATIA R, et al. Evaluation of the genetic fidelity of in vitropropagated gerbera (Gerbera jamesonii Bolus) using DNA-based markers. Plant Cell, Tissue and Organ Culture, 104:131-135, 2011.

BHATIA, R.; SINGH, K. P.; SINGH, M. C. In vitro mass multiplication of gerbera (Gerbera jamesonii) using capitulum explant. Indian Journal of Agricultural Sciences, 82(9):768-774, 2012.

CABALLERO, R. et al. Iron cholorosis in gerber as related to properties of various types of compost used as growing media. Communications in Soil Science and Plant Analysis, 38(17-18):2357-2369, 2007.

CARDOSO, J. C. et al. Pre-acclimatization in the greenhouse: An alternative to optimizing the micropropagation of gerbera. Scientia Horticulturae, 164:616-624, 2013.

CARDOSO,J.C.; TEIXEIRA DASILVA,J. A. Gerbera micropropagation. Biotechnology Advances, 31(8):1344-357, 2013.

CHAKRABARTY, D.; DATTA, S. K. Micropropagation of gerbera: Lipid peroxidation and antioxidant enzyme activities during acclimatization process. Acta Physiologiae Plantarum, 30:325-331, 2008.

DEWIR, Y. H. et al. Optimization of media formulation for axillary shoot multiplication of the red-peeled sweet potato, Ipomoea batatas (L.) Lam 'Abees. Chilean Journal of Agricultural Research, 80:3-10, 2020.

DRIVER, J. A.; SUTTLE, G. R. L. Nursery handling of propagules. In: BONGA, J. M.; DURZAN, D. J. (eds). Cell and tissue culture in forestry. Case histories: Gymnosperms, angiosperms and palms, v. 24-26. Springer, Dordrecht, p. 320-335, 1987.

FAKHRFESHANI, M. et al. Disinfecting effects of nano silver fluids in Gerbera (Gerbera jamesonii) capitulum tissue culture. Journal of Biological and Environmental Sciences, 6(17):121-127, 2012.

GANTAIT, S.; SINNIAH, U. R. In vitro direct rhizogenesis from Gerbera jamesonii Bolus leaf. Acta Physiologiae Plantarum, 36: 3081-3087, 2014.

GAUTAM, K. K., et al. Elimination of Cucumber mosaic virus from gerbera (Gerbera jamesonii) cv. Zingaro through in vitro chemotherapy of capitulum explants. Indian Journal of Biotechnology, 16:641-647, 2017.

KAMÍNEK, M. et al. The effect of two cytokinins on production of stem cuttings by stock plants of Euphorbia pulcherrima Willd. and Gerbera jamesonii Hook. Scientia Horticulturae, 33:281-289, 1987.

KANWAR, J. K.; KUMAR, S. In vitro propagation of Gerbera - A review. Horticultural Science, 35:35-44, 2008.
KASEM, M. Indirect micropropagation of Gerbera jamesonii Bolus cv. Winter Queen through callus redifferentiation. Journal of Plant Production, 9(4):307-314, 2018.

KHANAM, M. N. et al. meta-Topolin induced in vitro regeneration and metabolic profiling in Allamanda cathartica L. Industrial Crops and Products, 145:111944, 2020.

KISHI-KABOSHI, M.; AIDA, R.; SASAKI, K. Genome engineering in ornamental plants: Current status and future prospects. Plant Physiology and Biochemistry, 131:47-52, 2018.

KUCHARSKA, D. et al. Application of meta-Topolin for improving micropropagation of gooseberry (Ribes grossularia). Scientia Horticulturae, 272:109529, 2020.

LALTHAFAMKIMI, L. et al. Direct organogenesis mediated improvised mass propagation of Pogostemon cablin: A natural reserve of pharmaceutical biomolecules. South African Journal of Botany, 140:375-384, 2020.

LAVANYA, A. R. et al. In vitro micropropagation of Simarouba glauca DC. Indian Journal of Biotechnology, 15:107-111, 2016.

MANDAL, A. K. A.; DATTA, S. K. Introduction of gerbera cultivation in Lucknow agro-climate through tissue culture of young flower head. Indian Journal of Biotechnology, $1: 212-4,2002$.

MEYER, H. J.; VAN STADEN, J. The in vitro culture of Gerbera aurantiaca. Plant Cell, Tissue and Organ Culture, 14:25-30, 1988.

MOHAMMED, S. A.; ÖZZAMBAK, M. E. In vitro formation of Gerbera (Gerbera jamesonii Bolus) plantlets from capitulum explants. Propagation of Ornamental Plants, 7(1):37-42, 2007.

MOSQUEDA FRÓMETA, O. et al. In vitro propagation of Gerbera jamesonii Bolus ex Hooker F. in a temporary immersion bioreactor. Plant Cell, Tissue and Organ Culture, 129:543551, 2017.

MURASHIGE, T.; SERPA, M.; JONES, J. B. Clonal multiplication of Gerbera through tissue culture. HortScience, 9:175-180, 1974.

MURASHIGE, T.; SKOOG, F. A revised medium for rapid growth and bio assays with tobacco tissue cultures. Physiologae Plantarum, 15(3):473-497, 1962.

NHUT, D. T. et al. Effect of genotype, explant size, position, and culture medium on shoot generation of Gerbera jamesonii by receptacle transverse thin cell layer culture. Scientia Horticulturae, 111:146-151, 2007.

NIEDZ, R. P. et al. Mineral nutrition and in vitro growth of Gerbera hybrida (Asteraceae). In Vitro Cellular and Developmental Biology- Plant, 50:458-470, 2014. 
PARK, J. T. et al. A high-yielding standard gerbera cultivar with pink, semi-double flowers. Flower Research Journal, 26(3):147-151, 2018.

PIERIK, R. L. M.; STEEGMANS, H. H. M.; MARELIS, J. J. Gerbera plantlets from in vitro cultivated capitulum explants. Scientia Horticulturae, 1:117-119, 1973.

PIERIK, R. L. M. et al. Optimization of Gerbera plantlet production from excised capitulum explants. Scientia Horticulturae, 3(4):351-357, 1975.

PRAMANIK, D. et al. CRISPR-mediated engineering across the central dogma in plant biology for basic research and crop improvement. Molecular Plant, 14(1):127-150, 2021.

PREMKUMAR, G. et al. Cytokinin induced shoot regeneration and flowering of Scoparia dulcis L. (Scrophulariaceae): An ethnomedicinal herb. Asian Pacific Journal of Tropical Biomedicine, 1(3):169-172, 2011.

RASHMI, R. et al. Commercial multiplication of gerbera (Gerbera jamesonii Bolus ex. Hooker F.) from young capitulum explants. International Journal of Current Microbiology and Applied Science, 7:2524-2537, 2018.

RAY, T.; SAHA, P.; ROY, S. C. In vitro plant regeneration from young capitulum explants of Gerbera jamesonii. Plant Cell Biotechnology and Molecular Biology, 6:35-40, 2005.

ROYAL FLORA OF HOLLAND ANNUAL REPORT. 2017. Available in: https://np-royalfloraholland-production.s3-eu-west-1. amazonaws.com/3-Financieel/Documenten/Jaarverslagen/ royal-floraholland-jaarverslag-2017-NL.pdf. Access in: November, 6, 2021.

SHEKHAWAT, J. K. et al. Synergism of meta-Topolin with auxin and cytokinin enhanced micropropagation of Maytenus emarginata. In Vitro Cellular \& Developmental Biology Plant, 57(3):418-426, 2020.
SHEKHAWAT, M.S. et al. Meta-Topolin and liquid medium enhanced in vitro regeneration in Scaevola taccada (Gaertn.) Roxb. In Vitro Cellular \& Developmental Biology - Plant, 57:296-306, 2021.

SHIRIN, F.; RANA, P. K. In vitro plantlet regeneration from nodal explants of field-grown culms in Bambusa glaucescens Willd. Plant Biotechnology Reports, 1:1417, 2007.

SHYLAJA, M. R. et al. An efficient micropropagation protocol for Gerbera jamesonii Bolus. from flower buds. International Journal of Plant, Animal and Environmental Sciences, 4(3):641-643, 2014

TALLA, S. K. et al. Efficient TDZ-induced regeneration from capitulum explants of Gerbera jamesonii Bolus ex Hooker F. - An ornamental plant with high aesthetic value. Plant Biosystems, 153:679-685, 2019.

TYAGI, P.; KOTHARI, S. L. Rapid in vitro regeneration of Gerbera jamesonii $(\mathrm{H}$. Bolus ex Hook. F.) from different explants. Indian Journal of Biotechnology, 3:584-588, 2004.

WINARTO, B.; YUFDY, M. P. Establishment of in vitro propagation protocol of Gerbera jamesonii Bolus Ex Hook F.: Explant and media selection to plantlet acclimatization. Agraarteadus, 28:32-40, 2017.

WINARTO, B.; YUNIARTO, K.; SOEHENDI, R. Young capitulum as important explant in in vitro mass propagation of gerbera (Gerbera jamesonii). Notulae Scientia Biologicae, 12(2):264276, 2020

$X I A, Y$. et al. The world floriculture industry: Dynamics of production and markets. In: TEIXEIRA DA SILVA, J. A. (ed) Floriculture, ornamental and plant biotechnology: Advances and topical issues $1^{\text {st }}$ edn, vol IV. Global Science Books, Ltd., Isleworth, p. 336-347, 2006. 